\title{
Is God Hidden, Or Does God Simply Not Exist?
}

\author{
IAN M. CHURCH
}

HILLSDALE COLLEGE

ichurch@hillsdale.edu

"Why, O Lord, do you stand far away? Why do you hide yourself in times of trouble?"

Psalm 10:1, ESV

\section{Introduction}

The Black Death reached its climax in Europe from around 1346-1353. One of its salient features is that the Black Death did not seem to care just how pious or good its victim was - it afflicted the wicked and the virtuous all the same. The Black Death seemed to have little regard for social status or moral or religious character. People cried out to God for help and mercy, but God often seemed silent and hidden. ${ }^{1}$

And many of us have experienced something like this in our own lives. To many of us, in times of suffering, God can seem completely hidden. God can seem silent.

Of course, one of the things we see in these situations is the problem of evil. If God is all-good, all-powerful, and all-knowing, how can needless evil-including suffering of ostensibly innocent (if not good) people-happen? And given that such evil does occur, doesn't that at least cast doubt on the existence of such a God? But there is another, related worry lurking in the neighborhood. When God seems so silent and hidden - especially in times of tremendous need - this can create what we might call the existential problem of divine hiddenness. As Daniel Howard-Snyder and Paul Moser note, "The existential problem often takes the form of a crises of faith, sometimes leading to a collapse of trust in God" $(2002,1)$. To be sure, the experience of evil is not strictly necessary for the existential problem of divine hiddenness - God can seem hidden in benign times or even good times-but the

\footnotetext{
1 While there are interesting debates to be had regarding the nature and characteristics of God, in this chapter I will use "God" as the term is broadly understood in the Jewish and Christian traditions.
} 
experience of evil makes the apparent hiddenness of God all the more apparent and distressing. For many faiths, a personal relationship with God is incredibly important, and not just for any soteriological role such a relationship might play but for general human flourishing. As such, when God seems hidden-particularly in times of acute suffering and pain - this can create a serious existential problem indeed. As Howard-Snyder and Moser explain, if God seems hidden to the people in these faith communities "the world appears as an uncaring, inhospitable place. Despair over life itself then, is a natural result of divine hiddenness" $(2002,2)$.

While the existential problem of divine hiddenness is serious and broadly experienced, the philosophical literature has focused less on the existential angst posed by divine hiddenness and more on how the hiddenness of God poses a serious, evidential obstacle for theistic belief. In his seminal work, Divine Hiddenness and Human Reason (1993), John Schellenberg powerfully argued, in sum, that if God is perfectly loving, he would make it so that anyone capable of having a personal relationship with him would be able to reasonably believe that God exists. Given that some people do not believe in the existence of God-and after careful, sincere investigation and due to no fault of their own-then such a perfectly loving God does not exist.

In this essay, along with most of the contemporary philosophical literature, we will focus on the problem of divine hiddenness as an argument against theistic belief, and not as an existential problem. (As such, hereafter whenever I refer to the problem of divine hiddenness, I'm referring to the evidential argument against theistic belief and not the existential problem.)

\section{§1: A Summary of the Argument}

As I mentioned above, John Schellenberg's landmark book, Divine Hiddenness and Human Reason (1993), is the seminal work on the problem of divine hiddenness. As Daniel Howard-Snyder and Adam Green nicely summarize Schellenberg's argument:

(1) There are people who are capable of relating personally to God but who, through no fault of their own, fail to believe.

(2) If there is a personal God who is unsurpassably great, then there are no such people.

(3) So, there is no such God (from 1 and 2). (2016, sec. 2)

Obviously, if a theist wants to maintain their theism-and reject the conclusion of that argument - they need to be able to viably reject one of the two premises. At first blush, the first premise seems entirely incontrovertible and innocuous. It seems perfectly clear that if someone was from a society or culture that was relatively 
untouched by something like a traditional brand of theism, that they might live their entire lives without believing in God, due to no fault of their own. What is more, many atheists and agnostics seem to honestly and carefully consider the case for theism and don't become theists; and it might seem like a rare case indeed to discover an atheist or agnostic who rejects theism out of an explicit hatred for God or religion in general. Indeed, it seems like it would be tantamount to intellectual arrogance if a theist concluded that an atheist or an agnostic was somehow epistemically or intellectually derelict simply because they aren't theists. On what grounds could a theist challenge the intellectual integrity of every atheist and agnostic on this issue? As incontrovertible as this assumption seems to be it is nevertheless an assumption. Let's call it the no-fault assumption.

The second premise might seem a bit more suspect—or at least it doesn't seem as overtly plausible as the first premise - and so this might be what a theist looking to maintain their theism might first consider rejecting. After all, why think that a personal God who is unsurpassingly great would preclude the possibility of someone both (i) being capable of having a personal relationship to God and (ii) nevertheless failing to believe in the existence of God due to no fault of their own? Daniel Howard-Snyder and Adam Green helpfully summarize Schellenberg's argument for premise two (as it is found in his 1993 work):

(2a) If there is a personal God who is unsurpassably great, then there is a personal God who is unsurpassably loving.

(2b) If there is a personal God who is unsurpassably loving, then for any human person $\mathrm{H}$ and any time $\mathrm{t}$, if $\mathrm{H}$ is at $\mathrm{t}$ capable of relating personally to God, $\mathrm{H}$ has it within H's power at $\mathrm{t}$ to do so (i.e., will do so, just by choosing), unless $\mathrm{H}$ is culpably in a contrary position at $\mathrm{t}$.

(2c) For any human person $\mathrm{H}$ and any time $\mathrm{t}, \mathrm{H}$ has it within H's power at $\mathrm{t}$ to relate personally to God only if $\mathrm{H}$ at $\mathrm{t}$ believes that God exists.

(2d) So, if there is a personal God who is unsurpassably great, then for any human person $\mathrm{H}$ and any time $\mathrm{t}$, if $\mathrm{H}$ is at $\mathrm{t}$ capable of relating personally to God, $\mathrm{H}$ at $\mathrm{t}$ believes that God exists, unless $\mathrm{H}$ is culpably in a contrary position at $\mathrm{t}$ (from 2a through 2c).(2016, sec. 2)

And insofar as this conclusion (2d) is mean to be, as Howard-Snyder and Green put it "tantamount to [the second premise] of the main argument," this argument gives us a proof for the premise under consideration (2016, sec. 2). So if a theist wants to reject the second premise of the main argument (2) so as to maintain their theism, they will need to reject one of these premises that lead us to the conclusion of $2 \mathrm{~d}$. 
Few traditional theists (or at least theists from the Judeo-Christian tradition) would want to deny that God is unsurpassingly great or that he is unsurpassingly loving. While there might be some question about what it means for God to be unsurpassingly loving, few theists would want to deny outright that God has this characteristic. Premise 2 a seems fairly incontrovertible.

Likewise, it would be difficult for a theist to reject premise $2 \mathrm{c}$. It might seem pretty clear that someone can't have a personal relationship with an agent or thing if they don't think that agent or thing exists. ${ }^{2}$ Even in cases of non-existent imaginary friends, insofar as we're willing to grant that someone could have a personal relationship with a non-existent imaginary friend, we would presumably require that at least that person believe that their imaginary friend exists.

So that leaves the theist with premise $2 \mathrm{~b}$. Thankfully for the theist, there seems to be more room for disagreement here. That said, $2 b$ certainly seems to enjoy some intuitive plausibility. While there is certainly a lot to say here, the basic idea is that if God is personal and unsurpassably loving - as we granted with premise $2 \mathrm{a}$ - then such a God would make it so that people who are capable of having a relationship with him would be able to do so. Of course, that won't guarantee that everyone has a personal relationship with God-maybe due to rebellion or sin some people culpably resist. Given that being in a relationship with God is extremely desirableindeed, according to many theists, such a relationship is essential to human flourishing - we would reasonably expect a perfectly loving God to make it so that such a relationship is within everyone's grasp. If God was perfectly loving, then, non-culpable non-belief would not exist. ${ }^{3}$ But once we grant this, then it is going to seem difficult to reject the conclusion at $2 \mathrm{~d}$ and subsequently the conclusion at 3 . Let's call this the perfectly loving assumption. Of course a theist may respondindeed many theists do respond-by asking what exactly it means for God to be perfectly loving. If the case could be made that God could be perfectly loving without leading to the conclusion that non-culpable non-belief wouldn't existwithout entailing the idea that God would making his existence sufficiently manifest to everyone (or at least everyone capable of having a relationship with

\footnotetext{
${ }^{2}$ To be sure, this is actually a point of contention: As Howard-Snyder and Green ask, "might not a degree of confidence below the threshold of belief, or acceptance, or imagination-based assent, or belief-less assuming, or trust, or even hope suffice?" (2016, §4). See Alston 1996; Audi 2011; Cohen 1992; Howard-Snyder 2013; McKaughan 2013; Poston and Dougherty 2007; Schellenberg 2009; Schellenberg 2014
}

3For more on this, see pages 89-103 in Schellenberg's The Hiddenness Argument: Philosophy's New Challenge to Belief in God (2015). 
him) - then perhaps the conclusion of the Problem of divine hiddenness can be avoided.

\section{§2: Some Objections}

Perhaps the most prevalent strategy for rejecting the problem of divine hiddenness focuses on rejecting the perfectly loving assumption - the assumption that because God is perfectly loving he would make his existence sufficiently manifest to everyone (or at least everyone capable of having a relationship with him). In other words, many responses to the problem of divine hiddenness have tried to find a reason why a perfectly loving God would (either via comisson or omission) allow for situations where someone who is capable of a personal relationship with God nevertheless non-culpably fails to believe that God exists. ${ }^{4}$ Maybe sometimes God would allow for non-culpable non-belief of this sort because to make his existence manifestly clear (at least in some situations) would objectionably infringe upon a person's moral autonomy (see Murray 2002 and Swinburne 1979). Or maybe sometimes God would allow for non-culpable non-belief of that sort because beholding God's perfection and glory would make certain people (at certain times) jealous and resentful (see Dumsday 2012). Or maybe sometimes God allows for non-culpable non-belief of that sort in someone because they're interested in having a relationship with God for the wrong reasons (see Dumsday 2014; Moser 2002, 2008). If we could find reasons like these that a perfectly loving God might have for being hidden from people who would otherwise be capable of a relationship with God, then we might be able to find ways to reject the perfectly loving assumption and resist the problem of divine hiddenness's conclusion. ${ }^{5}$

And it's worth noting that such philosophical responses potentially have theological support-though such arguments don't rest on this support. For example, in Romans 9, the Apostle Paul controversially seems to give a picture of God where God chooses to have a salvific relationship with some while also choosing to withhold that relationship with others. For many, this is a troubling passage, and a tremendous amount of theological energy has been spent trying to unpack and exegete it. And while such exegesis is beyond the scope of this chapter, such passages could arguably serve as grounds for rejecting the second premise of

${ }^{4}$ For an excellent list and summary of responses like this see Howard-Snyder and Green (2016) §3.

${ }^{5}$ Or maybe the perfectly loving assumption is misguided because God is transcendent and somehow beyond our understanding of love (or personal in a personal relationship). See Rea 2016; Ross 2002; Trakakis 2016. Or maybe we could make the case that there could be reasons for God to hide himself from some people, but we simply don't know them. See Howard-Snyder 2016 and McBrayer and Swenson 2012. 
problem of divine hiddenness we saw in the previous section. They can be used to motivate rejecting the idea that God must be perfectly loving in such a way that would entail that he would make it so that anyone capable of having a personal relationship with him would be able to reasonably believe that God exists. Perhaps God has good reasons-or perhaps it is a part of his sovereign plan-for hiding himself from some people while revealing himself to others.

Other Biblical passages arguably lend credence to such a possibility. There are places in the book of Exodus where God explicitly seems to "harden the heart" of Pharaoh (see Exodus 4:21; 7:3; 9:12; 10:1; 10:20; 10:27; 11:10; 14:4;14:8). Similarly, in 1 Kings 22:19-23, God explicitly sends a "lying spirit" to deceive Ahab, the King of Israel, which eventually leads to his destruction. And given that having a "hardened heart" or a "lying spirit" seems to preclude having a healthy, personal relationship with God, then God doesn't seem to necessarily want to have a relationship with everyone, contra the perfectly loving assumption. And if God doesn't want a relationship with everyone then either he's not truly perfectly loving or being perfectly loving somehow doesn't entail wanting a relationship with everyone. In either case, there's arguably scriptural precedent for rejecting the second premise of the evidential problem of divine hiddenness.

Another strategy for responding to the problem of divine hiddenness is rejecting what seems like the far more incontrovertible and innocuous assumption, the nofault assumption. While this particular response has not enjoyed as much focused attention in the philosophical literature, it's worth mentioning at least briefly because certain religious communities might have theological or scriptural reasons for rejecting the no-fault assumption.

Paul's letter to the Romans again could arguably give someone material for rejecting what initially seems like a plausible assumption: that someone could be epistemically non-culpable in non-belief, be it atheism or agnosticism. In Romans 1:18-21, Paul seems to reject that assumption, implying that the existence of God has "been clearly perceived, ever since the creation of the world, in the things that have been made. So [that people who have suppressed the truth] are without excuse." And again, this isn't an isolated passage; other Biblical passages seem to point to similar conclusions. The writers of the Psalms seem to routinely find clear evidence for God in creation (see, for example, Psalm 19 and Psalm 148), and we see similar sentiment repeated elsewhere in the Old Testament (see, for example, Job 12 and Isaiah 55). Within the Jewish and Christian traditions, there seems to be an assumption that the presence of God is sufficiently manifest in the world. And as such, a theist from such a tradition could plausibly reject the first premise of the argument from divine hiddenness noted above. 
Both of these responses to divine hiddenness - the rejection of the assumption that God, being perfectly loving, wants a relationship with everyone and the rejection of the idea that non-belief can be non-culpable - face their own rejoinders. First of all, if we reject the idea that God is perfectly loving or the idea that being perfectly loving somehow entails wanting a relationship with everyone, then there is a real worry that we'll be left with a God who purposefully hides himself from some people-making a personal relationship with God extremely difficult, if not impossible, for those people. And if we think that having such a relationship with God is critically important for human flourishing-and depending on one's theological bent, singularly essential for one's eternal salvation-a God who willingly hides himself from some people seems, at least to many people, morally repugnant. ${ }^{6}$

Alternatively, if we reject the plausible assumption that someone can non-culpably reject theism (in the form of atheism or agnosticism) - the assumption that someone can carefully and honestly consider the evidence for theism and nevertheless remain agnostic or atheistic - then other worries need to be addressed. If two intellectual peers-interlocutors who are equally intelligent, informed, and educated-disagree about a particular issue, it would seem intellectually arrogant for one of them to simply dismiss out of hand the other's disagreement as disingenuous or the product of faulty (or sinful) cognitive faculties. That's not how productive, honest disagreements are suppose to work. As such, if a theist were to reject the problem of divine hiddenness on the grounds that atheism or agnosticism are the result of the noetic effects of sin or some cognitive malfunction, then the debate seems to grind to a halt. The theist, when employing such a strategy, seems antagonistic, unfriendly, and belligerent-leaving little common ground between theists and nontheists.

\section{Conclusion}

In summary, then, according to the evidential problem of divine hiddenness if God is perfectly loving, he would make it so that anyone capable of having a personal relationship with him would be able to reasonably believe that God exists. Given that some people do not believe in the existence of God-and after careful, sincere investigation and due to no fault of their own-then such a perfectly loving God does not exist. As we saw, however, such an argument rests on two key assumptions: the perfectly loving assumption, the assumption that because God is

${ }^{6}$ To be sure, however, it's worth noting that many theological traditions don't find such a view morally repugnant at all. The Calvinism of various strains of Protestantism is a great example of such a tradition. 
perfectly loving he would make his existence sufficiently manifest to everyone (or at least everyone capable of having a relationship with him); and the no-fault assumption, the assumption that someone can sincerely and honestly consider the question as to whether or not God exists and non-culpably maintain non-theistic belief (agnosticism or atheism).

Both assumptions can be rejected so as to avoid the problem of divine hiddenness's conclusion; however, doing so comes with challenges. If we are going to try to reject to the conclusion of the problem of divine hiddenness by denying the perfectly loving assumption, then special care needs to be taken to describe how God might be perfectly loving and yet purposefully hide himself from some people in certain circumstances or contexts. Alternatively, if we are going to try to reject the conclusion of the problem of divine hiddenness by denying the no-fault assumption, then it seems like special care needs to be taken to explain away nonbelief in a friendlier way-in a way that doesn't hide a blind arrogance or dogmatism.

Happily, the philosophical debate continues to develop. ${ }^{7}$ John Schellenberg among many others continue to refine and strengthen the problem-making it all the more problematic for theists! And research continues to develop that might help explain what it means for God to be perfectly loving and why God might sometimes be hidden for good reasons. Other theorists are developing new (and far more friendly) ways to explain non-belief (i.e. agnosticism and atheism), and others are exploring how unfriendly approaches might yet be correct. ${ }^{8}$

\section{Summary:}

In this chapter:

- We distinguished the existential problem of divine hiddenness from the evidential problem of divine hiddenness. The former being primarily concerned with the apparent hiddenness of a personal God in the lives of

\footnotetext{
${ }^{7}$ And some of this development draws from exciting new resources. In "No-fault Atheism" (2016), John Greco draws from contemporary research in social epistemology to give a friendly explanation for theistic non-belief. And the growing field of cognitive science of religion is also providing conceptual and empirical resources for explaining why some people have theistic beliefs while others don't. See Justin Barrett's seminal work, Why Would Anyone Believe in God? (2004).

${ }^{8}$ Research in this chapter was made possible thanks to a generous grant from the John Templeton Foundation. I dedicate this work to my beloved unborn child, Amias Noah Church, who we lost at the start of 2017, and who brought the hiddenness of God painfully to bear in my life.
} 
believers amidst terrible suffering. The latter being primarily concerned with the apparent hiddenness of God being evidence against God's existence.

- In the first section, we highlighted the basic contours of the evidential problem of divine hiddenness, and suggested that the argument rests on two important assumptions: the perfectly loving assumption and the no-fault assumption.

- In the second section, a few possible responses to the evidential problem of divine hiddenness were considered, which center on rejecting either the perfectly loving assumption or the no-fault assumption.

\section{Study Questions:}

1) If God is supposed to be perfectly loving, then should we expect him to sufficiently reveal himself to all rational agents capable of having a relationship with him? Why or why not?

2) What role can religious texts (e.g. the Bible) play in generating a philosophical response to the problem of divine hiddenness?

3) What relationship do you think the existential problem of divine hiddenness bears to the evidential problem of divine hiddenness?

4) How might the rejection of the no-fault assumption be perceived as intellectual arrogance? Does a commitment to intellectual humility commit us to the no-fault assumption?

5) Is there a viable, friendly way to reject the no-fault assumption?

6) Contemporary research in cognitive science of religion is making great strides in helping us empirically understand why some people have religious beliefs and others don't. How might this research be brought to bear to the problem of divine hiddenness?

7) Our religious beliefs (or lack thereof) are often shaped by our families, communities, and cultures. How might a better understanding of such influences be brought to bear on the problem of divine hiddenness?

\section{Suggested Introductory Readings}

- Barrett, Justin L. 2004. Why Would Anyone Believe in God? Walnut Creek, CA: AltaMira Press. [While not directly about the problem of divine hiddenness, this book brings together a lot of relevant empirical research into religious belief and non-belief.]

- Howard-Snyder, Daniel, and Paul K. Moser. 2002. "Introduction: The Hiddenness of God." In Divine Hiddenness: New Essays, edited by Daniel Howard-Snyder; Paul K. Moser. Cambridge University Press. [This is the introduction to the Howard-Snyer and Moser's edited collection on divine 
hiddenness, and it does an excellent job summarizing the relevant issues and debates.]

- Schellenberg, J. L. 1993. Divine Hiddenness and Human Reason. Ithaca: Cornell University Press. [This is arguably the seminal work that established the problem of divine hiddenness in the philosophical literature.]

- Garcia, Laura L. 2002. "St. John of the Cross and the Necessity of Divine Hiddenness." In Divine Hiddenness: New Essays, edited by Daniel HowardSnyder and Paul K. Moser, 83-97. Cambridge University Press. [An excellent introduction to the existential problem of divine hiddenness; although not the main focus of this chapter, this is an incredibly important variant of the problem of divine hiddenness.]

\section{Suggested Advanced Readings (3-5)}

- Green, Adam, and Eleonore Stump, eds. (2016) Hidden Divinity and Religious Belief: New Perspectives. Cambridge, United Kingdom: Cambridge University Press. [This book contains an excellent collection of leading, contemporary research on the problem of divine hiddenness and proposed solutions.]

- Schellenberg, J. L. 2015. The Hiddenness Argument: Philosophy's New Challenge to Belief in God. 1 edition. Oxford: Oxford University Press. [Schellenberg is the seminal figure within the divine hiddenness literature. This book showcases some of his most developed work on the issue.]

- Audi, Robert. 2011. Rationality and Religious Commitment. Oxford University Press. [In this chapter, I have assumed a very simple view of religious belief and commitment. That said, however, how we view religious faith and belief can have a substantial impact on how we perceive the problem of divine hiddenness. This book allows the reader to explore the rationality of religious belief and the nature of religious commitments in much greater detail.]

\section{Free Online Resources}

- Anon. 2017. "Argument from Nonbelief." Wikipedia. https://en.wikipedia.org/w/index.php?title=Argument_from_nonbelief \&oldid $=763750944$. [The Wikipedia page for the problem of divine hiddenness, which gives an excellent, basic overview of the argument and some possible objections to it.] 
- Howard-Snyder, Adam, Daniel; Green. 2016. "Hiddenness of God." The Stanford Encyclopedia of Philosophy. https://plato.stanford.edu/entries/divine-hiddenness/. [An excellent online introduction the problem of divine hiddenness-especially the evidential problem - and the relevant philosophical literature]

- Kraay, Klaas J. 2017. "The Problem of Divine Hiddenness - Philosophy - Oxford Bibliographies." Oxford Bibliographies. http://www.oxfordbibliographies.com/view/document/obo9780195396577/obo-9780195396577-0178.xml. [An excellent annotated bibliography on the problem of divine hiddenness; it summarizes the problem and the contours of the literature and points readers to other great resources.]

\section{Glossary of Key Terms}

Existential Problem of Divine Hiddenness: The angst generated by (i) the belief that a personal relationship with God is incredibly important for general human flourishing and (ii) the perception of God as hidden or silent-potentially resulting in a view of the world as uncaring and/or inhospitable.

Evidential Problem of Divine Hiddenness: An argument against the existence of God. In sum, if God is perfectly loving, he would make it so that anyone capable of having a personal relationship with him would be able to reasonably believe that God exists. Given that some such people do not believe in the existence of God, then such a perfectly loving God does not exist.

John Schellenberg: The leading figure in the divine hiddenness literature. His 1993 book, Divine Hiddenness and Human Reason, is often pointed to as the seminal work on the subject.

No-fault Assumption: the assumption that someone can sincerely and honestly consider the question as to whether or not God exists and nonculpably maintain non-theistic belief (agnosticism or atheism).

Non-Belief: Abstaining from theistic belief; atheism or agnosticism regarding the existence of God.

Non-Culpable: Not subject to blame. If someone was non-culpable in their atheistic or agnostic belief regarding the existence of God, then that means 
that they cannot be blamed for their belief (or lack of belief) - that they have sincerely and honestly looked into the issue and made the best decision with the evidence they had.

Perfectly-loving Assumption: the assumption that because God is perfectly loving he would make his existence sufficiently manifest to everyone or at least everyone capable of having a relationship with him.

\section{References}

Alston, William P. 1996. "Belief, Acceptance, and Religious Faith." In Faith, Freedom, and Rationality, ed. J Jordan and D. Howard-Snyder, 3-27. Lanham, MD: Rowman \& Littlefield.

Audi, Robert. 2011. Rationality and Religious Commitment. Oxford University Press.

Barrett, Justin L. 2004. Why Would Anyone Believe in God? Walnut Creek, CA: AltaMira Press.

Cohen, L. Jonathan. 1992. An Essay on Belief and Acceptance. Oxford: New York: Oxford University Press.

Greco, John. 2016. "No-fault Atheism." In Hidden Divinity and Religious Belief, ed. Adam Green and Eleonore Stump, 109-125. Cambridge University Press.

Green, Adam, and Eleonore Stump, eds. Hidden Divinity and Religious Belief: New Perspectives. Cambridge, United Kingdom: Cambridge University Press.

Howard-Snyder, Daniel. 2013. "Propositional Faith: What It Is and What It Is Not." American Philosophical Quarterly 50 (4): 357-372.

—_. 2016. "Divine Openness and Creaturely Nonresistant Nonbelief." In Hidden Divinity and Religious Belief: New Perspectives, ed. Adam Green and Eleonore Stump, 109-125. Cambridge: Cambridge University Press.

Howard-Snyder, Adam, Daniel; Green. 2016. "Hiddenness of God." The Stanford Encyclopedia of Philosophy. https://plato.stanford.edu/entries/divinehiddenness/.

Howard-Snyder, Daniel, and Paul K. Moser. 2002. "Introduction: The Hiddenness of God." In Divine Hiddenness: New Essays, edited by Daniel HowardSnyder; Paul K. Moser. Cambridge University Press.

McBrayer, Justin P., and Philip Swenson. 2012. "Scepticism About the Argument from Divine Hiddenness." Religious Studies 48 (2) (June): 129-150.

McKaughan, Daniel J. 2013. "Authentic Faith and Acknowledged Risk: Dissolving the Problem of Faith and Reason." Religious Studies 49 (1): 101-124. 
Rea, Michael C. 2016. "Hiddenness and Transcendence." In Hidden Divinity and Religious Belief, ed. Adam Green and Eleonore Stump, 210-225. Cambridge University Press.

Ross, Jacob Joshua. 2002. "The Hiddenness of God: A Puzzle or a Real Problem?" In Divine Hiddenness, ed. Daniel Howard and Paul Moser, 181-196. Cambridge University Press.

Schellenberg, J. L. 1993. Divine Hiddenness and Human Reason. Ithaca: Cornell University Press.

— 2009. The Will to Imagine: A Justification of Skeptical Religion. Cornell University Press.

— 2014. "How to Make Faith a Virtue." In Religious Faith and Intellectual Virtue, ed. Timothy O'Connor Laura Goins. Oxford University Press.

- 2015. The Hiddenness Argument: Philosophy's New Challenge to Belief in God. 1 edition. Oxford: Oxford University Press.

Trakakis, N. N. 2016. "The Hidden Divinity and What It Reveals." In Hidden Divinity and Religious Belief, ed. Adam Green and Eleonore Stump, 192209. Cambridge University Press. 